\title{
Review \\ The Pathophysiology and the Therapeutic Potential of Cannabinoids in Prostate Cancer
}

\author{
Kanika Singh ${ }^{1}$, Nazim Nassar ${ }^{2}$, Ava Bachari ${ }^{1}{ }^{\mathbb{D}}$, Ellen Schanknecht ${ }^{1}$, Srinivasareddy Telukutla $^{1}$, Roby $^{\text {Zomer }}{ }^{3}$, \\ Terrence J. Piva ${ }^{2}$ (D) and Nitin Mantri $1,4, * \mathbb{D}$
}

1 The Pangenomics Lab, School of Science, RMIT University, Bundoora, VIC 3083, Australia; s3704285@student.rmit.edu.au (K.S.); s3756626@student.rmit.edu.au (A.B.); s3664278@student.rmit.edu.au (E.S.); srinivasareddy.telukutla@rmit.edu.au (S.T.)

2 School of Health and Biomedical Sciences, RMIT University, Bundoora, VIC 3083, Australia; naz.nassar@rmit.edu.au (N.N.); terry.piva@rmit.edu.au (T.J.P.)

3 MGC Pharmaceuticals Limited, West Perth, WA 6005, Australia; roby@mgcpharma.com.au

4 The UWA Institute of Agriculture, The University of Western Australia, Perth, WA 6009, Australia

* Correspondence: nitin.mantri@rmit.edu.au; Tel.: +61-3-9925-7152

check for

updates

Citation: Singh, K.; Nassar, N.; Bachari, A.; Schanknecht, E.;

Telukutla, S.; Zomer, R.; Piva, T.J.;

Mantri, N. The Pathophysiology and the Therapeutic Potential of Cannabinoids in Prostate Cancer. Cancers 2021, 13, 4107. https:// doi.org/10.3390/cancers13164107

Academic Editors: Marco Falasca and Mauro Maccarrone

Received: 7 June 2021

Accepted: 13 August 2021

Published: 15 August 2021

Publisher's Note: MDPI stays neutral with regard to jurisdictional claims in published maps and institutional affiliations.

Copyright: (c) 2021 by the authors. Licensee MDPI, Basel, Switzerland. This article is an open access article distributed under the terms and conditions of the Creative Commons Attribution (CC BY) license (https:/ / creativecommons.org/licenses/by/ $4.0 /)$.
Simple Summary: Prostate cancer, after lung cancer, is the leading cause of death among men. The incidence rate of prostate cancer varies worldwide between regions and population groups. Its incidence increases with age and is more likely to occur in older men. Although the pathophysiological mechanisms and the etiological factors of prostate cancer development are still poorly understood, there are several factors associated with the risk of developing the disease such as age, family history, lifestyle-related factors (e.g., smoking, diet), and testosterone levels. Cannabinoids are an emerging class of pharmacological molecules that may exert their therapeutic effect against different cancers, including those from the prostate. Several studies have shown that various agonists are able to target cannabinoid receptors exhibited on prostate cancer cells. This affects the release of pro-inflammatory cytokines and has impacts on cell proliferation, cell apoptosis and necroptosis; consequently leading to the development of cancerous cells.

Abstract: Prostate cancer is the second most frequently occurring cancer diagnosed among males. Recent preclinical evidence implicates cannabinoids as powerful regulators of cell growth and differentiation. In this review, we focused on studies that demonstrated anticancer effects of cannabinoids and their possible mechanisms of action in prostate cancer. Besides the palliative effects of cannabinoids, research from the past two decades has demonstrated their promising potential as antitumor agents in a wide variety of cancers. This analysis may provide pharmacological insights into the selection of specific cannabinoids for the development of antitumor drugs for the treatment of prostate cancer.

Keywords: prostate cancer; cannabis; cannabinoids; cannabinoid receptors; cancer

\section{Introduction}

\subsection{The Prevalence of Prostate Cancer}

The incidence rate of prostate cancer varies worldwide between regions and population groups. According to the global cancer statistics in 2020, 1,414,259 new cases of prostate cancer were registered globally, representing $7.3 \%$ of all cancers in men [1]. The age-standardized rate was highest in Oceania (79.1 per 100,000 people) and North America (73.7), followed by Europe (62.1). Conversely, Africa and Asia have incidence rates (26.6 and 11.5, respectively) that are lower than those from developed countries [2]. Prostate cancer incidence increases with age and is more likely to occur in older men. Although only 1 in 350 men under the age of 50 years will be diagnosed with prostate cancer [3], the incidence rate increases to 1 in 52 men between 50 to 59 years. The incidence rate is 
close to $60 \%$ in men over 65 years [4]. Although the pathophysiological mechanisms and the etiological factors of prostate cancer development are still poorly understood, there are several factors associated with the risk of developing the disease such as age, family history, lifestyle-related factors (e.g., smoking, diet), and testosterone levels [5].

\subsection{Current Treatments in Prostate Cancer}

Treatment options for prostate cancer include radical prostatectomy [6], radiation therapy [7], prostate brachytherapy, cryotherapy [8], high intensity focused ultrasound [8], endocrine treatment, laparoscopic prostate surgery, chemotherapy, and androgen-deprivation therapy (ADT) [9]. ADT is utilised as the main treatment for metastatic hormone-sensitive prostate cancer [9]. Cattrini et al. [9], reported that the efficacy of the ADT treatment alone or in combination with conventional drugs such as docetaxel, abiraterone acetate, enzalutamide and apalutamide was low for prostate cancer [9].

The correlation between androgen receptors and the production of dihydrotestosterone (DHT) in the prostate is shown in Figure 1. DHT is prevented from binding to the androgen receptor (AR) in the cytoplasm, blocking the triggering of conformational changes and protein-protein interaction that lead to its nuclear translocation. Thus, pharmacological development is focussed on exploring new classes of anti-prostatic cancer drugs that can be utilized solely and/or as adjuvant therapies. The aim is to counteract the emerging resistance to the AR antagonists' pharmacological activity, lower affinity, greater side effects, and/or expensive approved therapy and to achieve more effective clinical outcomes.

\section{$\mathbf{A}$}

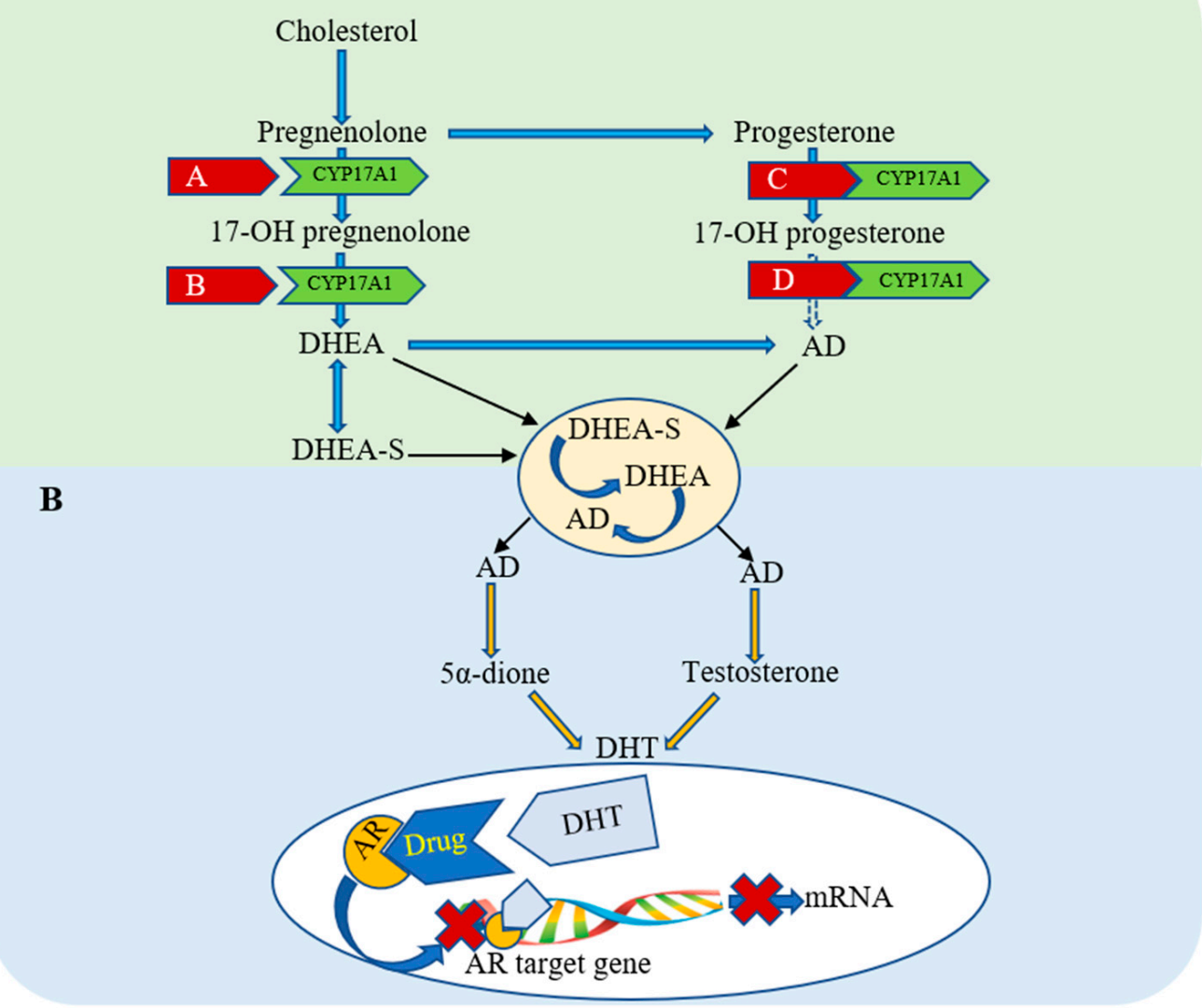

Figure 1. The schematic illustration demonstrates the: (A) Pharmacological inhibition of the production process of testostable 17. A1 gene. (B) Pharmacological inhibition of androgen receptor (AR) by competing with the prostate converted-adrenal androgens to dihydrotestosterone (DHT). 


\subsection{Cannabis sativa and Cannabinoids}

Plants have been used as traditional medicines for the treatment of numerous diseases. Recently, bioactive natural products are being used as an alternative therapy for prostate cancer, that offer fewer side effects compared to the conventional treatment of various prostate cancer cell lines such as cannabinoids obtained from the Cannabis sativa (C. sativa) plant. Cannabis has been known by numerous names such as hemp, hashish, bhang, and weed. C. sativa is one of the oldest cultivated plants and has been used for thousands of years, not only for its nutritional value but also for medicinal and textile applications $[10,11]$. It has been used in the treatment of various diseases due to its impacts as an analgesichypnotic, antiepileptic and antispasmodic, appetite stimulant, prophylactic, antidepressant, tranquiliser, antiasthmatic, oxytocic (stimulant of uterine contraction during childbirth), topical anesthetic, and antibiotic [12]. Since the 1990s it has emerged as an alternative therapeutic product for treatment of various fatal diseases such as epilepsy, multiple sclerosis, HIV, and cancer.

Cannabinoids are classified into three different categories based on their origin: (a) plant-originated cannabinoids that are found in the marijuana plant such as $\Delta 9$ tetrahydrocannabinol $\left(\Delta^{9}-\mathrm{THC}\right)$ as a psychoactive component of cannabis (phytocannabinoids) and the major non-intoxicating compound cannabidiol (CBD); (b) endocannabinoids including arachidonoyl ethanolamide (anandamide) and 2-arachidonoylglycerol (2-AG), which were found to be products of lipid membrane precursors in humans and animals, forming the endocannabinoid system (ECS) as a critical neuromodulatory system; and (c) synthetic molecules that mimic the structure of either plant or mammalian cannabinoids such as (R)-methanandamide (MET), WIN-55, and JWH-133 [13,14].

The $C$. sativa plant contains more than 500 known plant secondary metabolites, including cannabinoids, terpenes, and flavonoids [15]. The first class consists of cannabinoids such as CBD, $\Delta^{9}$-THC, cannabigerol, cannabichromene, cannabicyclol, cannabielsoin, cannabinol, cannabinodiol, and cannabitriol. Cannabinoids are mainly found in the resinous secretion produced by the trichomes of the plant. Over 150 cannabinoids have been isolated to date and derived from cannabigerolic acid [16]. Most of the phytocannabinoids do not possess psychoactive properties [17]. The second class of chemical constituents consists of the nitrogenous compounds such as quaternary bases amides, amines, spermidine alkaloids, amino acids, proteins, glycoproteins, and enzymes, sugars and related compounds (monosaccharides, disaccharides, polysaccharides, cyclitols, aminosugars), hydrocarbons (simple alcohols, simple aldehydes, simple ketones), simple acids (fatty acids, simple esters and lactones, steroids), terpenes (monoterpenes, sesquiterpenes, diterpenes, triterpenes and miscellaneous compounds of terpenoid origin), non-cannabinoid phenols, flavanoidglycosides, vitamins, and pigments. The total number of compounds known to occur in Cannabis is 421 with new compounds constantly being discovered and reported [18].

Synthetic cannabinoids (SCs) generate similar psychoactive and physiological effects to that of $\Delta^{9}$-THC. Castaneto et al. [19] reported that the pharmacological effects of SCs are up to 100 times more potent than $\Delta^{9}$-THC. Furthermore, SCs have great potential for their anti-inflammatory, anti-cancer, analgesic, weight-loss, and anti-seizure effects. Despite this, scientific research into both natural (phytocannabinoids) cannabinoids and SCs has continued. Studies are now being conducted on the potential efficacy of cannabinoids, both natural and synthetic, as anticancer agents and their possible mechanisms of action $[15,20,21]$.

\section{Cannabinoids and the Entourage Effect}

The term "Entourage effect" was first introduced by Mechoulam and his group in 1988 [22]. It refers to the contribution made by compounds (secondary metabolites) in increasing the effectiveness of primary cannabinoids (phyto or endo) in the body. This implies that the total effect of cannabinoids and secondary metabolites is greater than when these compounds are used alone. The whole plant extract has a superior effect 
in comparison to that of the individual isolated cannabinoids [23,24]. This synergistic interaction may occur between various cannabinoids, known as intra-entourage or between cannabinoids and terpenes, known as inter-entourage [25]. Ben-Shabat et al. reported this phenomenon for the first time in an in vivo study [22]. Their study confirmed the presence of 2-AG endogenous ligands, 2-linoleoyl-glycerol (2-Lino-Gl) and 2-palmitoyl-glycerol (2-Palm-Gl) in various tissues such as the spleen, brain and gut of a mice. They further stated that both the ligands 2-Lino-Gl and 2-Palm-Gl did not bind to the cannabinoid receptors, but they significantly enhanced the binding of 2-AG and its capacity in inhibiting adenylyl cyclase activity. Additionally, these esters considerably changed various motor responses caused by 2-AG in mice such as hypothermia and analgesia [22].

Several studies have further supported this mechanism and demonstrated that all the compounds present in the cannabis plant work together to produce the therapeutic effect [26,27]. Blasco-Benito et al. [27] demonstrated that the botanical drug preparation was more potent than pure $\Delta^{9}$-THC in both in vitro and in vivo models of breast cancer. Furthermore, LaVigne et al. [28] reported in a recent in vivo study that a combination of cannabis terpenes ( $\alpha$-humulene and $\beta$-pinene) with WIN55,212-2 produced additive effects in the activity of WIN55,212-2 on mice. The findings from these studies suggest that terpenes present in the cannabis plant play a significant role by synergistically improving the activity of isolated cannabinoids. However, so far there are a limited number of studies that have studied this mechanism. More research is warranted to confirm this synergistic activity among various compounds present in the cannabis plant.

\section{Cannabinoids as Pharmacological Effectors}

Cannabinoids are a new emerging class of pharmacological molecules that can exert their therapeutic effect against different tumors including prostatic cancer [13,29-32]. They bind to specific biological macromolecules exerting different physiological and behavioural responses [14]. Different studies showed that various agonists that target cannabinoid receptors, which are exhibited on cancer cells, can affect the release of anti-inflammatory cytokines, cell proliferation, and cell apoptosis and necroptosis, and consequently the development of cancer cells [29,33-36].

The pharmacological effect of cannabinoids is mediated through the stimulation of G protein-coupled receptors (GPCRs) called cannabinoid receptor type 1 (CB1) and cannabinoid receptor type 2 (CB2) [37]. CB1 receptors are located in the central nervous system (in the basal ganglia and the limbic system), as well as in non-neural tissues [38,39], while CB2 receptors are the peripheral receptors that are predominantly found in the immune system and the spleen [13,40-42]. The pharmacological response depends on the type of endogenous cannabinoid that binds to these receptors. It has been shown that the agonist efficacy of the 2-AG agent is high for CB1, whereas anandamide is a high-efficacy agonist for CB2 receptors [14].

Reviewing the literature concerning the pharmacodynamics of a wide range of different cannabinoids that have been researched over recent years, it is far less clear what and how their pharmacological effect is mediated through the convoluted ECS [43]. As discussed earlier, the ECS, including CB1, CB2, and their prominent extended glycoprotein family members form membrane cell-surface receptors, which mediate the pharmacological effect of the different cannabinoids. This distinctive group of glycoproteins consists of diverse G protein-coupled receptors (GPCRs) such as serotonin (5HT) receptors, orphan GPCRs (e.g., GPR18, GPR55, and GPR119), and ligand-gated ion channels [44-46]. These GPCRs are combined into GPCR oligomers through intermolecular forces, e.g., covalent bonding between the protomers forming homo/heteromeric dimers/trimers/or tetramers (Figure 2) $[44,47,48]$. 


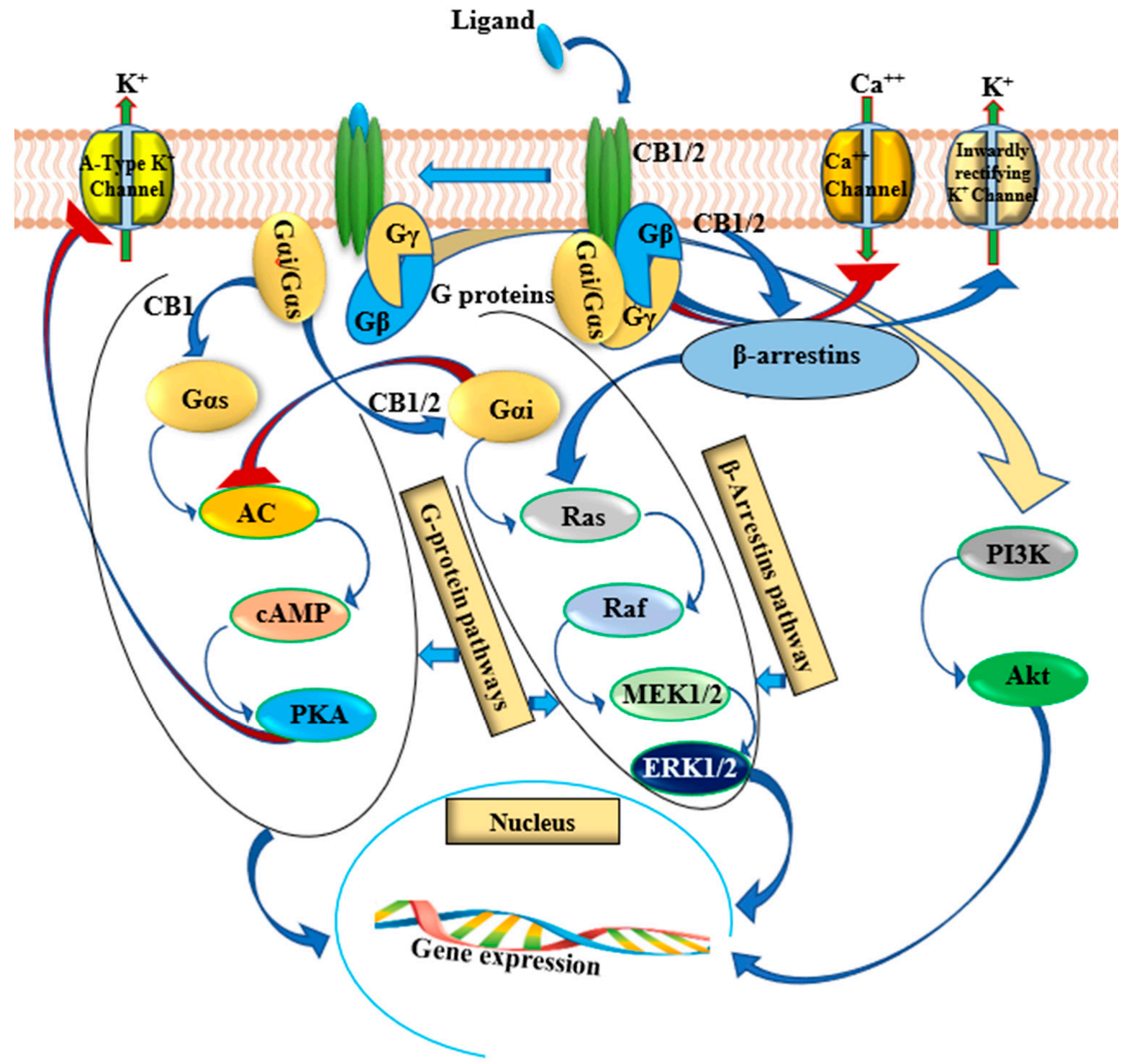

Figure 2. Signaling pathways activated by CB1 and CB2 receptors in prostate cancer cells. The coupling of Gi/o protein heteromers ( $\alpha \beta \gamma$ subunits) reduce intracellular cyclic adenosine monophosphate (cAMP) levels by inhibiting adenyl cyclase activity. Downregulated protein kinase A (PKA) suppresses PKA mediated signaling events. On dissociation of the $\alpha$ and $\beta \gamma$ subunits, phosphoinositol 3-kinase (PI3K) and protein kinase B are stimulated, which further induces the phosphorylation of mitogen activated protein kinase (MAPK). The CB1 receptor can switch G-protein coupling of Gi/o to Gs and Gq and activate several MAPKs such as ERK1/2, p38 and JNK under certain circumstances. CB1 also transduces non-G protein pathway signaling by activating $\beta$-arrestins. CB1-mediated signaling is dependent on the ligand and the sub-cellular environment. Arrows indicate stimulation/activation and blunted red arrows indicate inhibition.

Cannabinoid receptors are well known to form heteromers with a wide range of different receptors [44]. For example, CB1 interacts with GPCRs such as dopamine (D2) receptors, leading to changes in the coupling from Gi to Gs [49]. Moreover, Bonaventura and co-researchers have shown that $C B 1$ can interact simultaneously with adenosine (A2A) and D2 receptors forming A2A/CB1/D2 receptor heteromers that predict differential D2-mediated neurotransmission in the caudate-putamen of the dorsal striatum of the southeastern Asian long-tailed macque monkey Macaca fascicularis [50]. Nowadays, various CB1 and CB2-containing heteromeric GPCR oligomers have been found in cancer cells. In breast cancer cells, CB2 was found to form a heteromer with GPR55, and the tyrosine kinase receptor human V-Erb-B2 Avian Erythroblastic Leukemia Viral Oncogene Homolog 2 [44]. 
Heteromerisation has attracted the attention of scientists in recent years as a prominent potential target in cancer treatment amongst other chronic illnesses. Heteromers exhibit unique physicochemical properties associated with allosteric modulations. Such characteristics support those hybrid molecules to function as viable target sites and strategic platforms for different cannabinoid ligands treating a wide range of chronic diseases, including prostate cancer. Unlike the primary functional forms of plain monomeric receptors, they can lead to various and exemplary pharmacological and cellular functionalities that might influence the antitumor activity of the ECS depending on the combined properties of the complex heteromer and the applied pharmacological agent [51-53]. Precisely, the same ligand can display variable affinities to the same receptor (e.g., CB1 or CB2) and subsequently distinctive pharmacological effects, depending on the other partners involved in the unique heteromers in various tissues [53]. That is to say, designing a cannabinoid-based drug to treat prostate cancer is becoming a customised approach based on the heteromeric system, which is more likely to be a "disease-specific" marker [44].

Along with heteromerization as one of the most successfully targeted platforms for selective therapeutic agent innovation, the allostery of ligands is becoming another attractive area to explore cannabinoid-based drug discovery for various medical conditions. Hence, switching from the traditional approach of designing a highly conserved orthostatic agonist/antagonist mimicking the endogenous cannabinoids, e.g., AEA and 2-AG, to flexible allosteric ligands offers a new class of selective therapeutic molecules. These new molecules modulate GPCRs through allosteric sites, resulting in specific heteromeric alterations manifested as a positive/negative allosteric modulator, leading to fine-tuned cellular signaling without undesirable adverse reactions, which has gained tremendous interest during the last decade [54].

\subsection{Cell Signaling Mediated by Cannabinoid Receptors}

As mentioned above, the two cannabinoid receptors possess distinctive molecular structures. They are an integral part of the GPCR system, which undergoes configurational transformation following the binary interactions of the CB1/2 with different agonists, and the association of various intracellular signaling proteins associated with the distinctive complex of the $G$ protein $[55,56]$. This coupling system allows the CB1 and CB2 receptors to activate multiple pathways, which lead to markedly different responses based on various specific conformational stabilities depending on the cell type [56-59].

Moreover, cannabinoid receptors can transduce cell signaling through non- $G$ proteins pathways such as $\beta$-arrestins, as illustrated in Figure 2. Various GPCR ligands can exert their specific pharmacological effects by activating one specific signaling pathway over another. This phenomenon is called "biased agonism," manifested by triggering a selective intracellular cascade of events leading to a specific physiological outcome. For further information on this topic please refer to the following references $[44,48,52,60]$.

The activation of cannabinoid receptors CB1 and CB2 results in an inhibition of adenylyl cyclase resulting in reduced cAMP levels in most tissues [61]. Nevertheless, cannabinoid receptors have been shown to control other various signaling pathways that are directly involved in the regulation of cell proliferation and cell death. These signals include the extracellular-signal-regulated-kinase (ERK) as one of the major signaling pathways of the mitogen-activated protein kinase (MAPK) [62], and p38 MAPK [63], phosphatidylinositol 3-kinase (PI3K) / Akt [64], focal adhesion kinase [65], and ceramide and reactive oxygen species (ROS) pathways in prostate cancer [66].

\subsubsection{Cannabinoid-Induced Inhibition of Cell Proliferation}

The inhibitory effect of cannabinoids on cell proliferation has been known since 1974. Dixit et al. [67] observed a complete halt of spermatogenesis in mice after the daily administration of $2 \mathrm{mg}$ extract of cannabis for 45 days. Long-term exposure to 3-6 mg/ $\mathrm{kg}$ body weight per day of cannabinoids caused a dose-dependent reduction in gonadotropin 
releasing hormone 1 receptor protein expression in the pituitary gland, which reduced testosterone levels in male mice [68].

In recent years, attention has been drawn to the pharmacological potential of cannabis on prostate cancer. Several experimental studies have demonstrated and evaluated the effects of various cannabinoids in prostate tissue and prostate cancer cells, which contain both CB1 and CB2 receptors [13,29,30,69-72]. Louka et al. demonstrated, in DU145 and PC3 prostate cancer cells, that treatment with synthetic cannabinoids, AM-251 and AM-1241, inhibited the proliferation of these cells and increased DNA fragmentation only in DU145 cells [73]. They further stated that in DU145 cells, $48 \mathrm{~h}$ treatment with AM-251 and AM-1241 induced caspase dependent apoptosis. However, in PC3 cells, autophagy was induced via the PI3K/Akt/mTOR pathway. Pietrovito et al. demonstrated in a recent in vitro study that treatment with WIN55,212 inhibited migration of cancer associated fibroblasts of prostate cancer and this effect was mediated through the CB2 receptor [70]. Sarfaraz et al. [13] tested the synergistic effect of CB1 and CB2 agonists including WIN-55,212 in vitro on the following cell lines of prostate tissue: CA-human papillomavirus-10, LNCaP, CWR22Rv1, DU145, and PC3. They showed a dose- and time-dependent inhibition of cell growth; moreover, this effect was significantly blocked when the antagonists SR141716 and SR1444528 (CB1 and CB2 receptors, respectively) were introduced [29]. A dose and time-dependent induction of apoptosis, and reduction in PSA levels after the treatment of LNCaP cell line with WIN-55,212 synthetic cannabinoids was observed [29].

Nithipatikom et al. [74] tested the effect of 2-AG and noladin ether on the invasiveness of androgen-independent prostate cancer cell lines including PC 3 and DU145 as well as the androgen-dependent cell line LNCaP under the condition of hormone resistance in prostate cancer cells. The results showed that endogenous 2-AG leads to inhibition of androgen-independent PC3 and DU145 cells. This occurred by the invasion of these cells through the activation of the CB1 receptor; nevertheless, inhibition of 2-AG synthesis and antagonising the CB1 receptor results in increased cell invasion [74]. Detailed in vitro and in vivo studies indicating the effects of cannabinoids in prostate cancer are summarized in Table 1. 
Table 1. Effects of cannabinoid treatment on prostate cancer cells in in vitro and in vivo studies

\begin{tabular}{|c|c|c|c|c|c|c|}
\hline Cannabinoids & Cannabinoid Receptors & Prostate Cancer Cell Type & Mechanism of Action & Anticancer Effect & In Vitro/In Vivo & Citations \\
\hline WIN 55-212.2, CBD & CB1, CB2 & $\begin{array}{l}\text { CAFs, PC3, DU145, } \\
\text { LNCaP/PNT-1 }\end{array}$ & $\begin{array}{l}\text { Downregulates } \alpha \text {-smooth muscle actin and } \\
\text { matrix metalloprotease-2 expression, Inhibits } \\
\text { CAFs migration }\end{array}$ & $\begin{array}{c}\text { Cannabinoid inhibits CAF migration, impairs } \\
\text { the activation and the reactivity of CAFs } \\
\text { WIN } 55-212.2 \geq 5 \mu \mathrm{M} \text { and CBD } 5 \mu \mathrm{M} \\
\text { induces cell death in prostate cancer cell lines, } \\
\text { without affecting healthy prostate epithelial } \\
\text { cells }\end{array}$ & In vitro & [70] \\
\hline AM-251/ AM-1241 & & PC3, DU145 & $\begin{array}{l}\text { Induction of caspase-dependent apoptosis in } \\
\text { DU145 cells and autophagy in PC } 3 \text { cells }\end{array}$ & $\begin{array}{l}\text { Inhibition of the proliferation and reducing } \\
\text { viable cell number }\end{array}$ & In vitro & [73] \\
\hline WIN55,212-2 & CB2 & PC3, DU145, LNCaP & $\begin{array}{l}\text { Reduction in phosphorylated retinoblastoma } \\
\text { (pRb) and Cdk4 expression in a } \\
\text { dose-dependent manner; Increase in p27 } \\
\text { expression compared to control; WIN55,212-2 } \\
\text { exert its anti-proliferative effects partially } \\
\text { through the CB2 receptor. }\end{array}$ & $\begin{array}{l}\text { Cannabinoid Induces cell cycle arrest, } \\
\text { apoptosis and inhibits proliferation, } \\
\text { migration, invasion, and tumor growth in } \\
\text { prostate cancer }\end{array}$ & In vivo/In vitro & [71] \\
\hline WIN55,212-2 & CB2 & LNCaP & $\begin{array}{l}\text { Downregulated the PI3K/Akt/mTOR } \\
\text { signaling pathway; Activation of AMP }\end{array}$ & $\begin{array}{l}\text { Inhibition of neuroendocrine differentiation } \\
\text { (NE) and reduction in tumor size }\end{array}$ & In vitro/In vivo & [75] \\
\hline AEA, 2-AG, MET & CB1 & $\begin{array}{l}\text { PC3, Primary tissue samples from } \\
\text { patients }\end{array}$ & $\begin{array}{c}\text { Activated caspase-3-Down regulation of } \\
\text { Bcl-2- Activated the Erk pathway; Decrease in } \\
\text { the activation levels of the Akt pathway; } \\
\text { Activation of apoptotic pathway without } \\
\text { alteration in cell cycle }\end{array}$ & Inhibition of cell growth & In vitro & [76] \\
\hline CBD & $\begin{array}{l}\text { LNCaP-TRPM8 } \\
\text { PC3-CB1, CB2 } \\
\text { DU145-TRPV1 } \\
\text { 22RV1-TRPV1 }\end{array}$ & LNCaP, 22RV1, DU145, PC3 & $\begin{array}{c}\text { CBD induces intrinsic apoptotic pathway and } \\
\text { upregulated PUMA in all cell lines and AR in } \\
\text { LNCaP, 22RV1 } \\
\text { Increased expression of p27 and p21, G1/S } \\
\text { phase transition in LNCaP, 22RV1, DU145 } \\
\text { and PC3 } \\
\text { CBD-BDS dose-dependently inhibited the } \\
\text { growth of xenografts from LNCaP, but not } \\
\text { DU145 cells } \\
\text { CBD-BDS dose-dependently inhibited the } \\
\text { growth of xenografts from LNCaP but not } \\
\text { DU145 cells }\end{array}$ & Inhibition of cell viability and tumor growth & In vitro/In vivo & [77] \\
\hline $\begin{array}{c}\text { PM49 (synthetic } \\
\text { cannabinoid quinone) }\end{array}$ & $\begin{array}{l}\text { PPAR } \gamma \text { receptor and } \\
\text { partially CB1 }\end{array}$ & LNCaP & $\begin{array}{l}\text { ROS production, Cell cycle arrest in G0/G1 } \\
\text { phase; Apoptosis induction }\end{array}$ & $\begin{array}{l}\text { Inhibition of cell viability } \\
\text { Reduction in tumor growth }\end{array}$ & In vitro/In vivo & [78] \\
\hline WIN55212-2 & CB1 & PC3, DU145 & $\begin{array}{l}\text { Inhibition of small GTPase RhoA activity and } \\
\text { increases the Rac1 and Cdc42 activity; Loss of } \\
\text { actin/myosin microfilaments, cell spreading, } \\
\text { and cell migration }\end{array}$ & Decreased cell motility & In vitro & [79] \\
\hline WIN55212-2, CBD & $\mathrm{CB} 1, \mathrm{CB} 2$ & LNCaP & $\begin{array}{l}\text { WIN and CBD activate PARP cleavage and } \\
\text { induce apoptosis; WIN effects are CB receptor } \\
\text { independent; CBD effects are CB1 and CB2 } \\
\text { receptor dependent }\end{array}$ & $\begin{array}{l}\text { Cannabinoid induce phosphatases and } \\
\text { phosphatase-dependent apoptosis in cancer } \\
\text { cell lines. Inhibition of proliferation } \\
\text { Inhibition of cell growth }\end{array}$ & In vitro & [80] \\
\hline $\begin{array}{l}\text { JWH-015, } \\
\text { MET }\end{array}$ & CB2 & PC3, DU145, LNCaP & $\begin{array}{l}\text { Inhibits Akt-mTOR pathway; Induction of } d e \\
\text { novo synthesis of ceramide and ER stress- } \\
\text { proapoptotic effect-Included JNK activation }\end{array}$ & $\begin{array}{l}\text { Inhibition of cell growth } \\
\text { Reduction of tumor growth }\end{array}$ & In vitro/In vivo & [81] \\
\hline
\end{tabular}


Table 1. Cont.

\begin{tabular}{|c|c|c|c|c|c|c|}
\hline Cannabinoids & Cannabinoid Receptors & Prostate Cancer Cell Type & Mechanism of Action & Anticancer Effect & In Vitro/In Vivo & Citations \\
\hline WIN55,212-2 & CB1, CB2 & LNCaP, PC3 & $\begin{array}{c}\text { Induction of p53 and p27/KIP1, } \\
\text { Down-regulation of cyclins D1, D2, E and } \\
\text { E2F1; Decrease in the expression of cdk-2, }-4, \\
\text {-6, pRb, DP1 and DP2; Up-regulation of } \\
\text { ERK1/2 and inhibition of PI3k/Akt } \\
\text { pathways; Increase in Bax/Bcl-2 ratio- } \\
\text { Induction of apoptosis; G0/G1 phase cell } \\
\text { cycle arrest }\end{array}$ & $\begin{array}{l}\text { Inhibition of cell growth } \\
\text { Induction of apoptosis }\end{array}$ & In vitro & [37] \\
\hline $2 \mathrm{AG}$ & CB1 & PC3, DU145 & $\begin{array}{l}\text { Inhibits adenylyl cyclase and decreases } \\
\text { activity of PKA; Inhibition of invasion }\end{array}$ & Inhibition of invasion of prostate cancer cells & In vitro & [74] \\
\hline
\end{tabular}

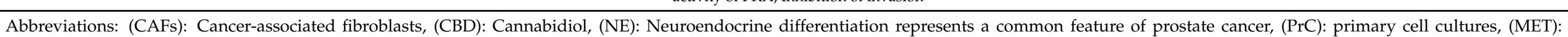

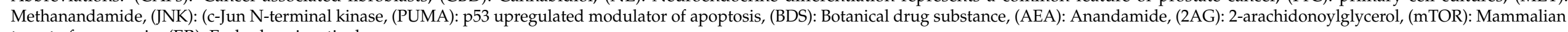
target of rapamycin, (ER): Endoplasmic reticulum. 


\subsubsection{Cannabinoid-Induced Apoptosis}

Administration of cannabinoid receptor agonists such as MET and WIN-55,212 to the culture of LNCaP and PC3 cell lines showed a significant decline of their growth This reduction in cell viability was associated with inhibition of Akt and activation of ERK $[29,37,81]$. Furthermore, the treatment of LNCaP cells with CB1 and CB2 agonists such as WIN-55,212 (1-10 $\mu \mathrm{M} ; 24 \mathrm{~h})$ respectively, showed a significant time- and dosedependent reduction in cell viability. It also resulted in cell cycle arrest in G0/G1 phase, initiation of p53 and p27/KIP1 genes, down-regulation of cyclins D1, D2, E, and a decrease in the expression of cdk-2, -4 , and -6 [37]. It has been suggested that cannabinoids exert their anticancer effects via initiating apoptosis due to the production of ceramide that enhances endoplasmic reticulum (ER) stress $[40,59,82]$. The accumulation of ceramide triggers the molecular mechanism that is mediated through the mammalian target of rapamycin (mTOR) pathway leading to the autophagy process [83]. Hence, the key mechanism of action by which cannabinoids work in a tumor cell is by inhibiting cancer cell proliferation and induction of cell death by apoptosis [32].

Salazar et al. [83] found that $\Delta^{9}$-THC triggered cytosolic ceramide accumulation leading to the activation of ER stress response, resulting in the initiation of factor $2 \alpha$ phosphorylation followed by the autophagy process. Furthermore, they suggested that autophagy resulted from the inhibition of the Akt/mTOR complex 1 (mTORC1) axis, which is mediated via the tribbles homolog 3-dependent signaling (TRIB3) [83] (Figure 3). OleaHerrero et al. [81] found that the activation of the CB2 receptor by synthetic cannabinoids such as anandamide analogue R(b)-MET, and JWH-015 exerted an antiproliferative effect in PC3 cells as a result of higher ceramide levels. Increased ceramide levels inhibited the Akt-mTOR pathway and activated the initiation factors involved in autophagy regulation as well as the ER stress response. Downregulation of the CB2 receptor led to an increase in viable cells after treatment with anandamide analogues. In vivo treatment with JWH-015 resulted in a significant reduction in tumor growth in mice [81].

Increased ceramide levels followed by an enhancement in ER stress triggered the activation of the caspase cascade leading to apoptosis [69]. Several other studies have demonstrated an increment in caspase-3 activity and reduction of Bcl-2 and Akt levels following the treatment of different prostate cancer cell cultures with endocannabinoid analogues [69,76]. Accumulation of ceramide and the down-regulation of epidermal growth factor receptor (EGFR) have been reported as anti-proliferative and apoptotic effectors generated by the endogenous cannabinoid anandamide in LNCaP, DU145, and PC 3 cells [84]. Ceramide has been linked to the upregulation of the stress-regulated protein, which is considered as a pivotal mediator of the anticancer activity of cannabinoids via its induction of apoptosis in those cells. Carracedo et al. [85] have shown that elevated p8 levels are dependent on de novo synthesized ceramide, and that this protein mediates its apoptotic effect through the upregulation of ER stress-related genes ATF-4, TRB3, and CHOP (Figure 3A), which may be potential therapeutic targets to be explored for tumor growth inhibition. Nevertheless, this pathway of apoptotic activation appears limited to tumor cells as normal cells are unaffected due to different cannabinoid-regulatory mechanisms involved in cell death and survival pathways [86].

Apoptosis can be also induced by ROS. Oxidative stress is a phenomenon generated by an imbalance between the overproduction of ROS in the cell and the under-detoxification of these reactive molecules throughout the cell's antioxidant capacity $[87,88]$. ROS are immensely reactive molecules that exist in different forms such as anion superoxide $\left(\mathrm{O}_{2}{ }^{-}\right)$, hydroxyl radical $(\mathrm{OH})$, and hydrogen peroxide $\left(\mathrm{H}_{2} \mathrm{O}_{2}\right)$. The high reactivity of these species is due to the presence of unpaired electrons whereby they can generate new reactive molecules or so-called free radicals, interacting with other biological molecules and leading to cellular injury $[89,90]$. Moderate levels of these free radicals are derived from molecular oxygen throughout the mitochondrial electron transport at the time of the aerobic aspiration. These radicals play a crucial role in cell signaling including triggering apoptosis and gene expression [91]. Nevertheless, different studies have linked oxidative stress with the 
initiation of a wide range of cancers $[69,89,92,93]$. The higher ROS levels in prostate cancer cells have been linked with a more invasive and hostile form of these tumors [94]. Targeting ROS production may offer a potential preventative treatment of prostate cancer.

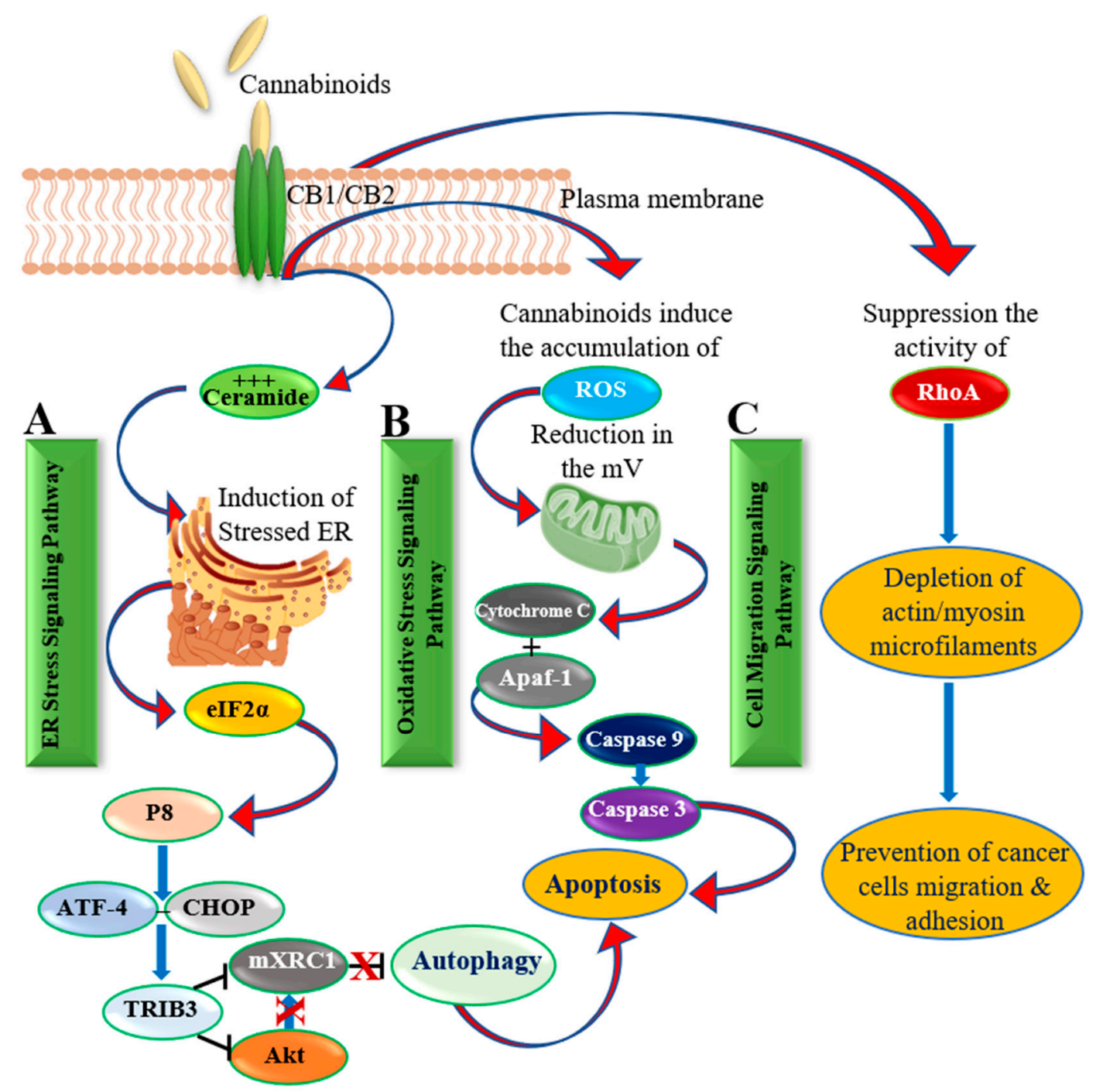

Figure 3. A schematic illustration shows the activation of cannabinoid receptors leading to (A). Accumulation of ceramide, which resulted in a build-up in ER stress followed by downstream signaling and induction of apoptosis; (B). Increasing the levels of ROS production followed by a reduction in the mitochondrial membrane potential and subsequent release of cytochrome c, and different caspases; (C). Inhibition of the RhoA production leading to loss of actin-myosin functionality and consequent reduction in cell migration.

Massi et al. [95] investigated whether the caspase cascade is involved with ROS induction that is mediated by CBD both in vitro and in vivo on U87 glioma cells. They observed that CBD generated a time-dependent caspase-3 apoptotic cell death following the induction of caspases- 8 and -9 as well as the release of cytochrome $c$. They also reported that CBD induced apoptosis and caspase activation occurs via increased ROS levels and glutathione depletion. The effect of the CBD on tumor cells was significantly higher than observed for normal cells due to their ability to generate ROS and activate the caspase cascade in transformed cells as depicted in Figure 3B [95].

The underlying molecular mechanisms of apoptosis that are induced by oxidative stress via cannabinoid receptors have been thoroughly investigated. De Petrocellis et al. [77] tested the effect of cannabinoid extracts on androgenic-receptor cell lines (LNCaP and 22RV1) as well as nonandrogenic-receptor cell lines (DU145 and PC3). They showed signif- 
icant inhibition in cell viability depending on the type of cannabinoid tested. Cannabinoids at different concentrations (1-10 mM) initiated the intrinsic apoptotic pathway. The proapoptotic effect of the experimented cannabinoids on LNCaP cells was only fractional owing to the transient receptor potential melastatin type-8 (TRPM8) antagonism and was chaperoned with the down-regulation of AR, p53 induction, and elevated ROS levels. These findings suggested that cannabinoids trigger the intrinsic apoptotic pathway and cell cycle arrest at the G1-S phase in prostate cancerous cells via ROS as seen in Figure 3B.

Dando et al. [96] used metabolomics to observe the effect of different CB1 and CB2 agonists on pancreatic tumor cells. Elevated AMP-activated protein kinase (AMPK) levels might be due to a ROS-dependent increase of the AMP / ATP ratio [96]. On the other hand, AMPK increases the level of glyceraldehyde 3-phosphate dehydrogenase. Moreover, the results have shown a proportional increase between ROS and NADH, which might be due to an inhibition of the electron respiratory chain and consequently the TCA cycle. Such alterations in cell metabolism, which are initiated by ROS after the mediation of cannabinoids can lead to inhibition of cell growth and the induction of autophagy [96].

\subsubsection{Cannabinoid-Induced Inhibition of Cell Motility}

Cannabinoids can be potential regulators of cell motility. Manipulation of cannabinoid receptor activity in different cell lines resulted in changes of cell motility $[97,98]$. It has been shown that manipulation of the phosphorylation of MAPK and focal adhesion kinase intermediates through cannabinoid usage leads to anti-tumoral effects in vitro including cell motility and cell-matrix adhesion in various types of tumors [98,99]. Cannabinoid receptors can activate Rho family proteins leading to an inhibition of cell migration as has been illustrated in Figure 3C.

Nithipatikom et al. [79] investigated the underlying molecular mechanism that inhibited cell migration in PC3, DU145 and LNCaP prostate cancer cells. The CB1 agonist WIN-55,212 significantly reduced RhoA GTPase activity, which was accompanied by the loss of actin/myosin microfilaments and consequent cell migration [79]. Moreover, the activity of the RhoA proteins was significantly increased after the administration of the CB1 antagonist AM251, leading to microfilament formation, which was followed by more cell spreading. Furthermore, the inhibition of RhoA activity due to loss of actin/myosin microfilaments in prostate cancer cell cultures was also observed after the administration of the exogenous CB1 agonist, anandamide [79]. On this basis, reducing cell motility through interference in the mediation of RhoA signaling via cannabinoids receptors represents another pharmacological application against prostate cancer. Furthermore, Roberto et al. reported that the synthetic cannabinoid WIN-55,212 significantly reduced the migration and invasive capacity of PC3 and DU145 prostate cancer cells in a dose dependent manner [71].

\section{Current Clinical Trials}

With respect to cancer, clinical trials demonstrating the effectiveness of cannabinoids are limited. A study in Australia is a phase I/II double blind trial assessing the effect of medicinal cannabis on the quality of life and symptom management in advanced cancer (ACTRN12619001534178) [100]. A randomised phase II trial on the effect of a single dose of $\mathrm{CBD}$ on anxiety in breast cancer patients prior to the CT scan to assess tumor burden (NCT04482244) is currently underway [101]. Another phase I/Ib study underway at the University of Kentucky (USA) is determining the safety and effectiveness of Epidiolex (CBD oil) in biochemically recurrent prostate cancer patients [102]. This clinical trial further aims to study whether Epidiolex is a safe treatment for older men with prostate cancer, and if there is any advantage to treating patients with the CBD oil while decreasing PSA and testosterone levels. Finally, the trial aims to identify if Epidiolex could lead to an improvement in the quality of life of prostate cancer patients (NCT04428203) [103]. It would be beneficial to perform further clinical studies using cannabinoids for patients with metastatic prostate cancer. Additionally, not only exploring their effects on prostate cancer 
but also investigating their analgesic properties for cancer pain associated with metastasis of cancer in the bone would be useful.

\section{Conclusions}

The significant knowledge of anti-tumor and palliative characteristics of cannabinoids acquired by the research community in the past few years has increased the utilization of these molecules as favorable candidates for cancer treatment. Although, the use of cannabis in medicine is restricted due to its psychoactive effects, cannabinoid-based treatments that lack the unwanted side effects are sought after. The lack of knowledge of how cannabis exerts its anticancer effects makes it even more complicated to find what is the best way these compounds can be used without these psychoactive effects. However, there is enough evidence in the literature stating the ability of cannabinoids to induce cell death by various pathways in prostate cancer, but there is still more research needed to be undertaken to understand their mechanism $[104,105]$. Although cannabinoids may well be able to help with management of prostate cancer, there is still an urgent need to identify the best and the most effective combination for these and other cancers. Furthermore, it is potentially desirable for cannabinoids to work on several hallmarks of cancer at one point in time. Many pre-clinical studies report the anti-tumor activity of cannabinoids $[31,72,106]$. An important aspect of cannabinoid pharmacology is their selectivity towards cancer cells and not to the normal cells in the body. Another aspect that needs more research is the identification of the mechanism of action by which cannabinoids show synergistic activity/entourage effect with other secondary plant metabolites.

Author Contributions: Conceptualization, K.S. and N.N.; writing-original draft preparation K.S. and N.N.; table-A.B. and E.S., writing—review and editing designed, E.S., S.T., R.Z., T.J.P. and N.M. All authors have read and agreed to the published version of the manuscript.

Funding: This research study is partly supported by MGC Pharmaceuticals Limited, Australia.

Data Availability Statement: The data presented in this study are available on request from the corresponding author.

Acknowledgments: K.S. is the recipient of the RMIT Research Stipend Scholarship from RMIT University, Australia.

Conflicts of Interest: The authors declare no conflict of interest.

\section{Abbreviations}

$\begin{array}{ll}\text { A2A } & \text { Adenosine } \\ \text { ADT } & \text { Androgen-deprivation therapy } \\ \text { AMPK } & \text { AMP-activated protein kinase } \\ \text { AR } & \text { Androgen receptor } \\ \mathrm{O}_{2}{ }^{-} & \text {Anion superoxide } \\ \text { AMPK } & \text { AMP-activated protein kinase } \\ \text { 2-AG } & \text { 2-arachidonoylglycerol } \\ \text { cAMPK } & \text { Cyclic adenosine monophosphate } \\ \text { CBD } & \text { Cannabidiol } \\ \text { CB1 } & \text { Cannabinoid receptor type 1 } \\ \text { CB2 } & \text { Cannabinoid receptor type 2 } \\ \text { DHEA } & \text { Dehydroepiandrosterone } \\ \text { D2 } & \text { Dopamine } \\ \text { DHT } & \text { Dihydrotestosterone } \\ \text { ECS } & \text { Endocannabinoid system } \\ \text { ER } & \text { Endoplasmic reticulum } \\ \text { ERK } & \text { Extracellular-signal-regulated-kinase } \\ \text { EGFR } & \text { Epidermal growth factor receptor } \\ \text { GPCRs } & \text { G protein-coupled receptors } \\ \text { OH } & \text { Hydroxyl radical }\end{array}$




$\begin{array}{ll}\mathrm{H}_{2} \mathrm{O}_{2} & \text { Hydrogen peroxide } \\ \text { 2-Lino-Gl } & \text { 2-linoleoyl-glycerol } \\ \text { mTOR } & \text { Mammalian target of rapamycin } \\ \text { MET } & \text { (R)-methanandamide } \\ \text { MAPK } & \text { Mitogen-activated protein kinase } \\ \text { 2-Palm-Gl } & \text { 2-palmitoyl-glycerol } \\ \text { PI3K } & \text { Phosphatidylinositol 3-kinase } \\ \text { PKA } & \text { Protein kinase A } \\ \text { PKB } & \text { Protein kinase B } \\ \text { ROS } & \text { Reactive oxygen species } \\ \text { 5HT } & \text { Serotonin } \\ \text { SC } & \text { Synthetic cannabinoids } \\ \Delta^{9} \text {-THC } & \Delta^{9} \text {-tetrahydrocannabinol } \\ \text { TRPM8 } & \text { Transient receptor potential melastatin type-8 } \\ \text { TRIB3 } & \text { Tribbles homolog 3-dependent signaling }\end{array}$

\section{References}

1. Sung, H.; Ferlay, J.; Siegel, R.L.; Laversanne, M.; Soerjomataram, I.; Jemal, A.; Bray, F. Global Cancer Statistics 2020: GLOBOCAN Estimates of Incidence and Mortality Worldwide for 36 Cancers in 185 Countries. CA A Cancer J. Clin. 2021, 71, 209-249. [CrossRef] [PubMed]

2. Ferlay, J.; Colombet, M.; Soerjomataram, I.; Mathers, C.; Parkin, D.; Piñeros, M.; Znaor, A.; Bray, F. Estimating the global cancer incidence and mortality in 2018: GLOBOCAN sources and methods. Int. J. Cancer 2019, 144, 1941-1953. [CrossRef] [PubMed]

3. Perdana, N.R.; Mochtar, C.A.; Umbas, R.; Hamid, A. The risk factors of prostate cancer and its prevention: A literature review. Acta Med. Indones. 2016, 48, 228-238. [PubMed]

4. Rawla, P. Epidemiology of Prostate Cancer. World J. Oncol. 2019, 10, 63-89. [CrossRef]

5. Leitzmann, M.F.; Rohrmann, S. Risk factors for the onset of prostatic cancer: Age, location, and behavioral correlates. Clin. Epidemiol. 2012, 4, 1-11. [CrossRef]

6. Kirby, R.S.; Patel, M.I. Fast Facts: Prostate Cancer; Health Press Limited: Oxford, UK, 2009.

7. Ramon, J.; Denis, L. Prostate Cancer (Recent Results in Cancer Research); Springer: Berlin/Heidelberg, Germany, 2007.

8. Dasgupta, P.; Kirby, R.S. ABC of Prostate Cancer; John Wiley \& Sons: Oxford, UK, 2011; Volume 159.

9. Cattrini, C.; Castro, E.; Lozano, R.; Zanardi, E.; Rubagotti, A.; Boccardo, F.; Olmos, D. Current treatment options for metastatic hormone-sensitive prostate cancer. Cancers 2019, 11, 1355. [CrossRef]

10. Makowiecka, J.; Wielgus, K. Therapeutic Potential of Cannabinoids-Retrospective and Historical Developments. J. Nat. Fibers 2014, 11, 185-198. [CrossRef]

11. Andre, C.M.; Hausman, J.-F.; Guerriero, G. Cannabis sativa: The plant of the thousand and one molecules. Front. Plant. Sci. 2016, 7, 19. [CrossRef]

12. Aldrich, M. History of Therapeutic Cannabis; McFarland \& Company, Inc., Publishers: Jefferson, CO, USA, 1997; pp. 35-55.

13. Sarfaraz, S.; Adhami, V.M.; Syed, D.N.; Afaq, F.; Mukhtar, H. Cannabinoids for cancer treatment: Progress and promise. Cancer Res. 2008, 68, 339-342. [CrossRef]

14. Lu, H.C.; Mackie, K. An Introduction to the Endogenous Cannabinoid System. Biol. Psychiatry 2016, 79, 516-525. [CrossRef]

15. Bridgeman, M.B.; Abazia, D.T. Medicinal cannabis: History, pharmacology, and implications for the acute care setting. Pharm. Ther. 2017, 42, 180.

16. Citti, C.; Linciano, P.; Russo, F.; Luongo, L.; Iannotta, M.; Maione, S.; Laganà, A.; Capriotti, A.L.; Forni, F.; Vandelli, M.A.; et al. A novel phytocannabinoid isolated from Cannabis sativa L. with an in vivo cannabimimetic activity higher than $\Delta 9$ tetrahydrocannabinol: $\Delta$ 9-Tetrahydrocannabiphorol. Sci. Rep. 2019, 9, 20335. [CrossRef]

17. Kocis, P.T.; Vrana, K.E. Delta-9-tetrahydrocannabinol and cannabidiol drug-drug interactions. Med. Cannabis Cannabinoids 2020, 3 , 12-24. [CrossRef]

18. Turner, C.E.; Elsohly, M.A.; Boeren, E.G. Constituents of Cannabis sativa L. XVII. A review of the natural constituents. J. Nat. Prod. 1980, 43, 169-234. [CrossRef]

19. Castaneto, M.S.; Gorelick, D.A.; Desrosiers, N.A.; Hartman, R.L.; Pirard, S.; Huestis, M.A. Synthetic cannabinoids: Epidemiology, pharmacodynamics, and clinical implications. Drug Alcohol Depend. 2014, 144, 12-41. [CrossRef]

20. Cridge, B.J.; Rosengren, R.J. Critical appraisal of the potential use of cannabinoids in cancer management. Cancer Manag. Res. 2013, 5, 301.

21. Ladin, D.A.; Soliman, E.; Griffin, L.; van Dross, R. Preclinical and clinical assessment of cannabinoids as anti-cancer agents. Front. Pharmacol. 2016, 7, 361. [CrossRef]

22. Ben-Shabat, S.; Fride, E.; Sheskin, T.; Tamiri, T.; Rhee, M.-H.; Vogel, Z.; Bisogno, T.; de Petrocellis, L.; Di Marzo, V.; Mechoulam, R. An entourage effect: Inactive endogenous fatty acid glycerol esters enhance 2-arachidonoyl-glycerol cannabinoid activity. Eur. J. Pharmacol. 1998, 353, 23-31. [CrossRef] 
23. Russo, E.; Guy, G.W. A tale of two cannabinoids: The therapeutic rationale for combining tetrahydrocannabinol and cannabidiol. Med. Hypotheses 2006, 66, 234-246. [CrossRef]

24. Russo, E.B. Taming THC: Potential cannabis synergy and phytocannabinoid-terpenoid entourage effects. Br. J. Pharmacol. 2011, 163, 1344-1364. [CrossRef] [PubMed]

25. Namdar, D.; Voet, H.; Ajjampura, V.; Nadarajan, S.; Mayzlish-Gati, E.; Mazuz, M.; Shalev, N.; Koltai, H. Terpenoids and phytocannabinoids co-produced in Cannabis sativa strains show specific interaction for cell cytotoxic activity. Molecules 2019, 24, 3031. [CrossRef] [PubMed]

26. Hecksel, R.; LaVigne, J.; Streicher, J.M. In Defense of the "Entourage Effect": Terpenes Found in Cannabis sativa Activate the Cannabinoid Receptor 1 In vitro. FASEB 2020, 34, 1. [CrossRef]

27. Blasco-Benito, S.; Seijo-Vila, M.; Caro-Villalobos, M.; Tundidor, I.; Andradas, C.; García-Taboada, E.; Wade, J.; Smith, S.; Guzmán, M.; Pérez-Gómez, E. Appraising the "entourage effect": Antitumor action of a pure cannabinoid versus a botanical drug preparation in preclinical models of breast cancer. Biochem. Pharmacol. 2018, 157, 285-293. [CrossRef] [PubMed]

28. LaVigne, J.; Hecksel, R.; Streicher, J.M. In Defense of the "Entourage Effect": Terpenes Found in Cannabis sativa Activate the Cannabinoid Receptor 1 In vivo. FASEB 2020, 34, 1. [CrossRef]

29. Sarfaraz, S.; Afaq, F.; Adhami, V.M.; Mukhtar, H. Cannabinoid receptor as a novel target for the treatment of prostate cancer. Cancer Res. 2005, 65, 1635-1641. [CrossRef]

30. Ramos, J.A.; Bianco, F.J. The role of cannabinoids in prostate cancer: Basic science perspective and potential clinical applications. Indian J. Urol. 2012, 28, 9-14. [CrossRef]

31. Malhotra, P.; Casari, I.; Falasca, M. Therapeutic potential of cannabinoids in combination cancer therapy. Adv. Biol. Regul. 2021, 79, 100774. [CrossRef]

32. Śledziński, P.; Zeyland, J.; Słomski, R.; Nowak, A. The current state and future perspectives of cannabinoids in cancer biology. Cancer Med. 2018, 7, 765-775. [CrossRef]

33. Scheau, C.; Badarau, I.A.; Mihai, L.G.; Scheau, A.E.; Costache, D.O.; Constantin, C.; Calina, D.; Caruntu, C.; Costache, R.S.; Caruntu, A. Cannabinoids in the Pathophysiology of Skin Inflammation. Molecules 2020, 25, 652. [CrossRef]

34. Coussens, L.M.; Werb, Z. Inflammation and cancer. Nature 2002, 420, 860-867. [CrossRef]

35. Neagu, M.; Constantin, C.; Caruntu, C.; Dumitru, C.; Surcel, M.; Zurac, S. Inflammation: A key process in skin tumorigenesis. Oncol. Lett. 2019, 17, 4068-4084. [CrossRef]

36. Petrosino, S.; Verde, R.; Vaia, M.; Allarà, M.; Iuvone, T.; Di Marzo, V. Anti-inflammatory Properties of Cannabidiol, a Nonpsychotropic Cannabinoid, in Experimental Allergic Contact Dermatitis. J. Pharmacol. Exp. Ther. 2018, 365, 652-663. [CrossRef]

37. Sarfaraz, S.; Afaq, F.; Adhami, V.M.; Malik, A.; Mukhtar, H. Cannabinoid receptor agonist-induced apoptosis of human prostate cancer cells LNCaP proceeds through sustained activation of ERK1/2 leading to G1 cell cycle arrest. J. Biol. Chem. 2006, 281, 39480-39491. [CrossRef]

38. Devane, W.A.; Dysarz, F.A.; Johnson, M.R.; Melvin, L.S.; Howlett, A.C. Determination and characterization of a cannabinoid receptor in rat brain. Mol. Pharmacol. 1988, 34, 605-613.

39. Matsuda, L.A.; Lolait, S.J.; Brownstein, M.J.; Young, A.C.; Bonner, T.I. Structure of a cannabinoid receptor and functional expression of the cloned cDNA. Nature 1990, 346, 561-564. [CrossRef]

40. Velasco, G.; Sánchez, C.; Guzmán, M. Anticancer mechanisms of cannabinoids. Curr. Oncol. 2016, 23, S23. [CrossRef]

41. Munro, S.; Thomas, K.L.; Abu-Shaar, M. Molecular characterization of a peripheral receptor for cannabinoids. Nature 1993, 365, 61-65. [CrossRef]

42. Vayalil, P.K. Mitochondrial oncobioenergetics of prostate tumorigenesis. Oncol. Lett. 2019, 18, 4367-4376. [CrossRef]

43. Franco, R.; Rivas-Santisteban, R.; Reyes-Resina, I.; Casanovas, M.; Pérez-Olives, C.; Ferreiro-Vera, C.; Navarro, G.; Sánchez de Medina, V.; Nadal, X. Pharmacological potential of varinic-, minor-, and acidic phytocannabinoids. Pharmacol. Res. 2020, 158, 104801. [CrossRef]

44. Moreno, E.; Cavic, M.; Krivokuca, A.; Casadó, V.; Canela, E. The Endocannabinoid System as a Target in Cancer Diseases: Are We There Yet? Front. Pharmacol. 2019, 10, 339. [CrossRef]

45. Zou, S.; Kumar, U. Cannabinoid Receptors and the Endocannabinoid System: Signaling and Function in the Central Nervous System. Int. J. Mol. Sci. 2018, 19, 833. [CrossRef]

46. Morales, P.; Reggio, P.H. An Update on Non-CB1, Non-CB2 Cannabinoid Related G-Protein-Coupled Receptors. Cannabis Cannabinoid Res. 2017, 2, 265-273. [CrossRef]

47. Salon, J.A.; Lodowski, D.T.; Palczewski, K. The significance of G protein-coupled receptor crystallography for drug discovery. Pharmacol. Rev. 2011, 63, 901-937. [CrossRef]

48. Ferré, S.; Casadó, V.; Devi, L.A.; Filizola, M.; Jockers, R.; Lohse, M.J.; Milligan, G.; Pin, J.P.; Guitart, X. G protein-coupled receptor oligomerization revisited: Functional and pharmacological perspectives. Pharmacol. Rev. 2014, 66, 413-434. [CrossRef]

49. Glass, M.; Felder, C.C. Concurrent stimulation of cannabinoid CB1 and dopamine D2 receptors augments cAMP accumulation in striatal neurons: Evidence for a Gs linkage to the CB1 receptor. J. Neurosci. 1997, 17, 5327-5333. [CrossRef] [PubMed]

50. Bonaventura, J.; Rico, A.J.; Moreno, E.; Sierra, S.; Sánchez, M.; Luquin, N.; Farré, D.; Müller, C.E.; Martínez-Pinilla, E.; Cortés, A.; et al. L-DOPA-treatment in primates disrupts the expression of $\mathrm{A}(2 \mathrm{~A})$ adenosine-CB(1) cannabinoid-D(2) dopamine receptor heteromers in the caudate nucleus. Neuropharmacology 2014, 79, 90-100. [CrossRef] 
51. Jin, J.; Momboisse, F.; Boncompain, G.; Koensgen, F.; Zhou, Z.; Cordeiro, N.; Arenzana-Seisdedos, F.; Perez, F.; Lagane, B.; Kellenberger, E.; et al. CCR5 adopts three homodimeric conformations that control cell surface delivery. Sci. Signal. 2018, 11, eaal2869. [CrossRef]

52. Nemoto, W.; Yamanishi, Y.; Limviphuvadh, V.; Saito, A.; Toh, H. GGIP: Structure and sequence-based GPCR-GPCR interaction pair predictor. Proteins 2016, 84, 1224-1233. [CrossRef]

53. Cortes, A.; Moreno, E.; Rodriguez-Ruiz, M.; Canela, E.I.; Casado, V. Targeting the dopamine D3 receptor: An overview of drug design strategies. Expert Opin. Drug Discov. 2016, 11, 641-664. [CrossRef] [PubMed]

54. Conn, P.J.; Christopoulos, A.; Lindsley, C.W. Allosteric modulators of GPCRs: A novel approach for the treatment of CNS disorders. Nat. Rev. Drug Discov. 2009, 8, 41-54. [CrossRef]

55. Cabrera-Vera, T.M.; Vanhauwe, J.; Thomas, T.O.; Medkova, M.; Preininger, A.; Mazzoni, M.R.; Hamm, H.E. Insights into G protein structure, function, and regulation. Endocr. Rev. 2003, 24, 765-781. [CrossRef] [PubMed]

56. Ibsen, M.S.; Connor, M.; Glass, M. Cannabinoid CB(1) and CB(2) Receptor Signaling and Bias. Cannabis Cannabinoid Res. 2017, 2, 48-60. [CrossRef] [PubMed]

57. Smith, T.H.; Sim-Selley, L.J.; Selley, D.E. Cannabinoid CB1 receptor-interacting proteins: Novel targets for central nervous system drug discovery? Br. J. Pharmacol. 2010, 160, 454-466. [CrossRef] [PubMed]

58. Scotter, E.; Graham, S.; Glass, M. Cannabinoid Receptor Signal Transduction Pathways. In The Cannabinoid Receptors; Reggio, P.H., Ed.; Humana Press: Totowa, NJ, USA, 2009; pp. 153-171.

59. Ibsen, M.S.; Finlay, D.B.; Patel, M.; Javitch, J.A.; Glass, M.; Grimsey, N.L. Cannabinoid CB1 and CB2 Receptor-Mediated Arrestin Translocation: Species, Subtype, and Agonist-Dependence. Front. Pharmacol. 2019, 10, 350. [CrossRef]

60. Ye, L.; Cao, Z.; Wang, W.; Zhou, N. New Insights in Cannabinoid Receptor Structure and Signaling. Curr. Mol. Pharmacol. 2019, 12, 239-248. [CrossRef]

61. Turu, G.; Hunyady, L. Signal transduction of the CB1 cannabinoid receptor. J. Mol. Endocrinol. 2010, 44, 75-85. [CrossRef]

62. Dalton, G.D.; Howlett, A.C. Cannabinoid CB1 receptors transactivate multiple receptor tyrosine kinases and regulate serine/threonine kinases to activate ERK in neuronal cells. Br. J. Pharmacol. 2012, 165, 2497-2511. [CrossRef]

63. Neves, L.M.S.; Gonçalves, E.C.D.; Cavalli, J.; Vieira, G.; Laurindo, L.R.; Simões, R.R.; Coelho, I.S.; Santos, A.R.S.; Marcolino, A.M.; Cola, M.; et al. Photobiomodulation Therapy Improves Acute Inflammatory Response in Mice: The Role of Cannabinoid Receptors/ATP-Sensitive K(+) Channel/p38-MAPK Signalling Pathway. Mol. Neurobiol. 2018, 55, 5580-5593. [CrossRef]

64. De Assis Lima, I.V.; Bellozi, P.M.; Batista, E.M.; Vilela, L.R.; Brandão, I.L.; Ribeiro, F.M.; Moraes, M.F.D.; Moreira, F.A.; de Oliveira, A.C. Cannabidiol anticonvulsant effect is mediated by the PI3K $\gamma$ pathway. Neuropharmacology 2020, 176, 108156. [CrossRef]

65. Malenczyk, K.; Jazurek, M.; Keimpema, E.; Silvestri, C.; Janikiewicz, J.; Mackie, K.; Di Marzo, V.; Redowicz, M.J.; Harkany, T.; Dobrzyn, A. CB1 cannabinoid receptors couple to focal adhesion kinase to control insulin release. J. Biol. Chem. 2013, 288, 32685-32699. [CrossRef]

66. Cheratta, A.R.; Thayyullathil, F.; Pallichankandy, S.; Subburayan, K.; Alakkal, A.; Galadari, S. Prostate apoptosis response-4 and tumor suppression: It's not just about apoptosis anymore. Cell Death Dis. 2021, 12, 47. [CrossRef]

67. Dixit, V.; Sharma, V.; Lohiya, N. The effect of chronically administered cannabis extract on the testicular function of mice. Eur. J. Pharmacol. 1974, 26, 111-114. [CrossRef]

68. Banerjee, A.; Singh, A.; Srivastava, P.; Turner, H.; Krishna, A. Effects of chronic bhang (cannabis) administration on the reproductive system of male mice. Birth Defects Res. B Dev. Reprod. Toxicol. 2011, 92, 195-205. [CrossRef]

69. Dariš, B.; Verboten, M.T.; Knez, Ž.; Ferk, P. Cannabinoids in cancer treatment: Therapeutic potential and legislation. Bosn. J. Basic Med. Sci. 2019, 19, 14. [CrossRef]

70. Pietrovito, L.; Iozzo, M.; Bacci, M.; Giannoni, E.; Chiarugi, P. Treatment with Cannabinoids as a Promising Approach for Impairing Fibroblast Activation and Prostate Cancer Progression. Int. J. Mol. Sci. 2020, 21, 787. [CrossRef]

71. Roberto, D.; Klotz, L.H.; Venkateswaran, V. Cannabinoid WIN 55,212-2 induces cell cycle arrest and apoptosis, and inhibits proliferation, migration, invasion, and tumor growth in prostate cancer in a cannabinoid-receptor 2 dependent manner. Prostate 2019, 79, 151-159. [CrossRef]

72. Fraguas-Sánchez, A.I.; Torres-Suárez, A.I. Medical Use of Cannabinoids. Drugs 2018, 78, 1665-1703. [CrossRef]

73. Louka, S.; Neophytou, C.; Constantinou, A. Abstract 4030: Synthetic cannabinoids AM-251 and AM-1241 induce cell death in prostate cancer cells. Cancer Res. 2020, 80, 4030.

74. Nithipatikom, K.; Endsley, M.P.; Isbell, M.A.; Falck, J.R.; Iwamoto, Y.; Hillard, C.J.; Campbell, W.B. 2-Arachidonoylglycerol: A novel inhibitor of androgen-independent prostate cancer cell invasion. Cancer Res. 2004, 64, 8826-8830. [CrossRef]

75. Morell, C.; Bort, A.; Vara, D.; Ramos-Torres, A.; Rodriguez-Henche, N.; Diaz-Laviada, I. The cannabinoid WIN 55,212-2 prevents neuroendocrine differentiation of LNCaP prostate cancer cells. Prostate Cancer Prostatic Dis. 2016, 19, 248-257. [CrossRef]

76. Orellana-Serradell, O.; Poblete, C.; Sanchez, C.; Castellon, E.; Gallegos, I.; Huidobro, C.; Llanos, M.; Contreras, H. Proapoptotic effect of endocannabinoids in prostate cancer cells. Oncol. Rep. 2015, 33, 1599-1608. [CrossRef]

77. De Petrocellis, L.; Ligresti, A.; Schiano Moriello, A.; Iappelli, M.; Verde, R.; Stott, C.G.; Cristino, L.; Orlando, P.; Di Marzo, V. Non-THC cannabinoids inhibit prostate carcinoma growth in vitro and in vivo: Pro-apoptotic effects and underlying mechanisms. Br. J. Pharmacol. 2013, 168, 79-102. [CrossRef] 
78. Morales, P.; Vara, D.; Goméz-Cañas, M.; Zúñiga, M.C.; Olea-Azar, C.; Goya, P.; Fernández-Ruiz, J.; Díaz-Laviada, I.; Jagerovic, N. Synthetic cannabinoid quinones: Preparation, in vitro antiproliferative effects and in vivo prostate antitumor activity. Eur. J. Med. Chem. 2013, 70, 111-119. [CrossRef]

79. Nithipatikom, K.; Gomez-Granados, A.D.; Tang, A.T.; Pfeiffer, A.W.; Williams, C.L.; Campbell, W.B. Cannabinoid receptor type 1 (CB1) activation inhibits small GTPase RhoA activity and regulates motility of prostate carcinoma cells. Endocrinology 2012, 153, 29-41. [CrossRef]

80. Sreevalsan, S.; Joseph, S.; Jutooru, I.; Chadalapaka, G.; Safe, S.H. Induction of apoptosis by cannabinoids in prostate and colon cancer cells is phosphatase dependent. Anticancer Res. 2011, 31, 3799-3807.

81. Olea-Herrero, N.; Vara, D.; Malagarie-Cazenave, S.; Diaz-Laviada, I. Inhibition of human tumour prostate PC-3 cell growth by cannabinoids R (+)-Methanandamide and JWH-015: Involvement of CB 2. Br. J. Cancer 2009, 101, 940-950. [CrossRef]

82. Velasco, G.; Hernández-Tiedra, S.; Dávila, D.; Lorente, M. The use of cannabinoids as anticancer agents. Prog. NeuroPsychopharmacol. Biol. Psychiatry 2016, 64, 259-266. [CrossRef]

83. Salazar, M.; Carracedo, A.; Salanueva, Í.J.; Hernández-Tiedra, S.; Lorente, M.; Egia, A.; Vázquez, P.; Blázquez, C.; Torres, S.; García, S. Cannabinoid action induces autophagy-mediated cell death through stimulation of ER stress in human glioma cells. J. Clin. Investig. 2009, 119, 1359-1372. [CrossRef] [PubMed]

84. Hermanson, D.J.; Marnett, L.J. Cannabinoids, endocannabinoids, and cancer. Cancer Metastasis Rev. 2011, 30, 599-612. [CrossRef] [PubMed]

85. Carracedo, A.; Lorente, M.; Egia, A.; Blázquez, C.; García, S.; Giroux, V.; Malicet, C.; Villuendas, R.; Gironella, M.; González-Feria, L. The stress-regulated protein p8 mediates cannabinoid-induced apoptosis of tumor cells. Cancer Cell 2006, 9, 301-312. [CrossRef] [PubMed]

86. Guzman, M. Cannabinoids: Potential anticancer agents. Nat. Rev. Cancer. 2003, 3, 745-755.

87. Pizzino, G.; Irrera, N.; Cucinotta, M.; Pallio, G.; Mannino, F.; Arcoraci, V.; Squadrito, F.; Altavilla, D.; Bitto, A. Oxidative stress: Harms and benefits for human health. Oxid. Med. Cell. Longev. 2017, 2017, 8416763. [CrossRef]

88. Dhakal, S.; Kushairi, N.; Phan, C.W.; Adhikari, B.; Sabaratnam, V.; Macreadie, I. Dietary Polyphenols: A Multifactorial Strategy to Target Alzheimer's Disease. Int. J. Mol. Sci. 2019, 20, 5090. [CrossRef]

89. Phaniendra, A.; Jestadi, D.B.; Periyasamy, L. Free radicals: Properties, sources, targets, and their implication in various diseases. Indian J. Clin. Biochem. 2015, 30, 11-26.

90. Signorile, A.; Ferretta, A.; Ruggieri, M.; Paolicelli, D.; Lattanzio, P.; Trojano, M.; de Rasmo, D. Mitochondria, Oxidative Stress, cAMP Signalling and Apoptosis: A Crossroads in Lymphocytes of Multiple Sclerosis, a Possible Role of Nutraceutics. Antioxidants 2020, 10, 21. [CrossRef]

91. Perillo, B.; di Donato, M.; Pezone, A.; di Zazzo, E.; Giovannelli, P.; Galasso, G.; Castoria, G.; Migliaccio, A. ROS in cancer therapy: The bright side of the moon. Exp. Mol. Med. 2020, 52, 192-203. [CrossRef]

92. Hayes, J.D.; Dinkova-Kostova, A.T.; Tew, K.D. Oxidative Stress in Cancer. Cancer Cell 2020, 38, 167-197.

93. Ebrahimi, S.O.; Reiisi, S.; Shareef, S. miRNAs, oxidative stress, and cancer: A comprehensive and updated review. J. Cell Physiol. 2020, 235, 8812-8825. [CrossRef]

94. Aggarwal, V.; Tuli, H.S.; Varol, A.; Thakral, F.; Yerer, M.B.; Sak, K.; Varol, M.; Jain, A.; Khan, M.A.; Sethi, G. Role of Reactive Oxygen Species in Cancer Progression: Molecular Mechanisms and Recent Advancements. Biomolecules 2019, 9, 735. [CrossRef]

95. Massi, P.; Vaccani, A.; Bianchessi, S.; Costa, B.; Macchi, P.; Parolaro, D. The non-psychoactive cannabidiol triggers caspase activation and oxidative stress in human glioma cells. Cell. Mol. Life Sci. 2006, 63, 2057-2066.

96. Dando, I.; Donadelli, M.; Costanzo, C.; Dalla Pozza, E.; D’alessandro, A.; Zolla, L.; Palmieri, M. Cannabinoids inhibit energetic metabolism and induce AMPK-dependent autophagy in pancreatic cancer cells. Cell Death Dis. 2013, 4, e664. [CrossRef]

97. Hohmann, T.; Grabiec, U.; Ghadban, C.; Feese, K.; Dehghani, F. The influence of biomechanical properties and cannabinoids on tumor invasion. Cell Adh. Migr. 2017, 11, 54-67. [CrossRef]

98. Hohmann, T.; Feese, K.; Ghadban, C.; Dehghani, F.; Grabiec, U. On the influence of cannabinoids on cell morphology and motility of glioblastoma cells. PLoS ONE 2019, 14, e0212037. [CrossRef]

99. Dalton, G.D.; Peterson, L.J.; Howlett, A.C. CB $_{1}$ cannabinoid receptors promote maximal FAK catalytic activity by stimulating cooperative signaling between receptor tyrosine kinases and integrins in neuronal cells. Cell. Signal. 2013, 25, 1665-1677. [CrossRef] [PubMed]

100. Australian Government. Clinical Trial Cancer-Australia. Available online: https:/ /www.australianclinicaltrials.gov.au (accessed on 24 June 2021).

101. Clinical Trial Breast Cancer-USA. Available online: https: / clinicaltrials.gov/ct2/show /NCT04482244 (accessed on 24 June 2021 ).

102. Myint, Z.; St Clair, W.H.; Strup, S.; Wang, P.; James, A.C.; Yan, D.; Allison, D.B.; Ellis, C.S.; Otto, D.E.; Kolesar, J.; et al. A phase I, dose-expansion cohort study on the safety of a cannabidiol for biochemical recurrence in prostate cancer patients. J. Clin. Oncol. 2021, 39, TPS263. [CrossRef]

103. Clinical Trial Prostate Cancer-USA. Available online: https: / clinicaltrials.gov/ct2/ show /NCT04428203 (accessed on 24 June 2021 ).

104. Bachari, A.; Piva, T.J.; Salami, S.A.; Jamshidi, N.; Mantri, N. Roles of Cannabinoids in Melanoma: Evidence from In vivo Studies. Int. J. Mol. Sci. 2020, 21, 6040. [CrossRef] 
105. Singh, K.; Jamshidi, N.; Zomer, R.; Piva, T.J.; Mantri, N. Cannabinoids and Prostate Cancer: A Systematic Review of Animal Studies. Int. J. Mol. Sci. 2020, 21, 6265. [CrossRef]

106. Roberto, D.; Klotz, L.H.; Venkateswaran, V. Cannabinoids as an Anticancer Agent for Prostate Cancer. J. Urol. Res. 2017, 4, 1090-1097. 